\title{
Impact of Brechtian theory on Girish Karnad: An Analysis of Hayavadana and Yayati
}

\author{
Deepa Kumawat ${ }^{1}$,Iris Ramnani ${ }^{2}$ \\ ${ }^{1}$ Assistant Professor, Department of English, S.V.Govt.P.G.College, Neeemuch, (M.P.), India \\ ${ }^{2}$ Guest Lecturer, Department of English, S.V.Govt.P.G.College,Neemuch, (M.P.),India
}

\begin{abstract}
Drama is very popularly known as the 'fifth Veda'. Since ages the concept of drama has been to provide entertainment \& pleasure to the audience. The Indian as well as Western playwrights have written plays with instruction and entertainment as their objectives. But what actually is the effect of these plays on the audience? Many theorists have given their principles on the dramatic ends and Aristotle is the most prominent among them who has proposed 'catharsis' as the function of drama. The present paper throws light on the impact of Brechtian theory on Girish Karnad's two plays 'Hayavadava' and 'Yayati' as opposed to the principles foregrounded by Aristotle. In the postcolonial stance the mimetic theory of Aristotle is replaced by the 'Epic Theatre' of Bertolt Bercht which depicts the function of drama as 'anti-cathartic'. He mentions that the resultant effect of drama is not only to evoke the elements of pity \& fear but make the audience think about the cause and effect of the play. Being influenced by the Brechtian theatre Karnad uses it in the Indian context and adds new dimensions to the Indian theatre. This paper explores how Girish Karnad exploits the traditional myths in the modernized terms and reflects Brechtian impact on the above mentioned plays.
\end{abstract}

Keywords: anti-cathartic, Brechtian theory, catharsis, mimetic theory, myths.

\section{Introduction}

The contemporary Indian English theatre is a mirror reflecting the conjunction of past and present in a myriad ways. From the very beginning the Indian dramaturgy is influenced by the Sanskrit folk and western dramatic traditions. The panorama of Indian English drama is bound by history, lineage, folklore and mythology. All these aspects link the theatre to the past and are highly significant as they serve as the roots and soil; nourishing and sustaining the Indian mind. Owing to the legacy of the British regime and the western education, the twentieth century Indian English drama becomes a blend of the east and the west. The drying sap of Indian drama was revitalized by the great Indian dramatists such as Nissim Ezekiel, Asif Currimbhoy, Mahesh Dattani, Vijay Tendukar and Girish Karnad. All these playwrights enrich the contemporary society delving deep into the myth and history of Indian culture. Among these well-known dramatists Girish Karnad is a versatile writer who has not only contributed a lot to the Indian English Drama but has also shown his ability as an actor, director, poet, script writer and translator. He is one of the former generation of Indian playwrights who have made efforts in reshaping the Indian theatre and initiated in framing his dramatic range when there was a direct clash - between the cultural past of the country and its colonial past, between the attractions of Western modes of thought and our own traditions and finally between the various visions of future that opened up once the common cause of political freedom was achieved". [1]

Although rich in tragedy the Indian mind does not assess the tragic situation exactly in the manner of the west. The various dramatists mentioned above have made sporadic efforts to amalgamate the eastern and western tradition of theatre. The present paper is an endeavour to illustrate the impact of western dramatic principles over contemporary Indian English drama. For this we have analyzed the waves of Aristotelian concept of dramaturgy, its evidential opposition by a German playwright Bertolt Brecht and finally his idea of Epic theatre and non-Aristotelian approach practiced by a popular Indian English playwright Girish Karnad in his plays Hayavadna and Yayati.

\section{Western Dramatic Concepts and Brecht's Non- Aristotelian Theatre}

For more than 2000 years the great Greek philosopher and theoretician Aristotle propounded principles of dramaturgy. His theories remained unchallenged with respect to the creation and production of a play. According to Aristotle's principles - tragedy is a higher form of drama than epic due to its concentration and economy. It must essentially have a certain magnitude and leave a cathartic effect on the audience, purging the emotions of pity and fear. He defines tragedy as,

"tragedy is the imitation of an action that is serious and also, as having magnitude, complete in itself...... in a dramatic not in a narrative form; with incidents arousing pity and fear wherewith to accomplish its catharsis of such emotions."[2] 
But this idea of tragedy was questioned by a German playwright Bertolt Brecht, who advocated the "non Aristotelian" theatre. He leads his way to a rejection of Aristotle's term catharsis, empathy and imitation in favour of "alienation effect". Being a rationalist Brecht, combined the past theatrical traditions and arrived at the concept of theatre of alienation. He demanded a theater of critical thoughtfulness which he called as an "Epic Theatre." His non-Aristotelian Epic Theatre substitutes the elements of pity and fear with a readiness to help and an eagerness to know causality respectively.

Karnad was influenced by certain important aspects of Brechtian theory such as 'alienation effect', 'interruptive devices', 'complex seeing' and 'anti- cathartic effect' but discovered them in his own theatrical tradition". [3] Considerably disillusioned and dissatisfied by the established theatre he chose the "epic theatre" as proposed by Brecht which heightens the alienation effect in the audience. He successfully adopted the Brechtian dramaturgy in his plays. Like Brecht, Karnad employs history to achieve "alienation effect." Bentley explains the paradoxical position of history plays: "historical plays are unhistorical." [4] Efficiently using the mythological traditions in his plays Karnad has tried to modernize his themes, focusing on the identity crisis in Hayavadna and malcontent in Yayati. R.K Dhawan opines "it is a well known fact that the real success of a play can be tested on stage. A playwright needs a living theatre to put his work on acid test, evaluate its total effect on the audience and thereby get a chance to improve upon his performance." [5] And Brecht's epic theatre proved to be a living stage for Karnad where the audience was left not just purgating their latent emotions but analyzing and commenting on the situation of the dramatic characters.

\subsection{Hayavadana}

III. Theory and Practice in the light of Identity Crisis and Alienation Effect

The play Hayavadana is based on a tale from 'Vetalpanchavimshika' and follows the theme of the "search for completeness." Inspite of considering it just as a tale of fantasy Karnad has relied on Thomas Mann's reworking of the tale in The Transposed Heads. The Indian tale poses a moral problem but the Western ideology considered by Mann depicts the human body as a fit instrument for the fulfillment of human destiny. Juxtaposing the Western influence on the Indian mythology Karnad mentions that even the transposition of heads will not liberate the protagonists from their natural psychological demands. In Hayavadana Karnad employs native folk theatre strategies to present man's tragically futile aspiration for perfection. For Karnad, the confusion of the identities reveals the ambiguous nature of the human personality which goes in accordance with the Brechtian theory of identity crisis. The two protagonists in Hayavadna - Devdatta with an intellectual mind and Kapila with a robust physique suffer from deformity and incompleteness. Agony strikes Kapila and makes him to think about the dissatisfaction and in human life. He questions "why should one tolerate this mad dance of incompleteness." [6] As Brecht aimed to subvert the sympathy of the audience with the actors and the identification of actor with his role, Karnad also dealt with the interpretation of the ancient Indian story which not only differs substantially from his originals but also indicates a bold attempt at investing an old legend with a new meaning. This proves to be an urgent relevance to present day thinking about man and his world. Brecht's main idea was to encourage his audience to criticize and oppose rather than passively accept what the eyes are seeing in the same way in the play Hayavadana the protagonist with a horse's head laments his fate. This story gets resolved when the half horse, half man which goes by the dictates of the supremacy of head over body turns entirely into a horse. He is born to a Karnataka princess and is sired by an Arabian horse-and obvious trope for land and lady. It is thus for Hayavadna (horse headed man); to find solution to his predicament. Since God does not enable him to overcome it, he rushes on stage to the Bhagavata. It is here that the dramatist brings the case to court so the audience can judge it. Brecht wanted to distance or alienate his audience from the character and the action; in the play Hayavadna, Karnad also aimed to make certain distance emotionally from the characters and the action on stage, so that the audience could be able to reach such an intellectual level of understanding. In this process while alienated emotionally from the action and the characters, the audience would be empowered on an intellectual level both to analyze and perhaps even to try to change the world, which was Brecht's social and political goal as a playwright and the driving force behind his dramaturgy. The various Indian dramatic conventions as the use of Bhagavata, unrelated episodes and the mixing of human and non- human world in Hayavadana facilitates a 'complex seeing' in the audience. He is the connecting link to introduce the other characters and action in the play and a sort of vehicle to reveal the deepest thought of a major character. Karnad opines that they "permit the simultaneous presentation of alternative points of view, of alternative altitudes to the central problem."'[1] As in the scene in Act II where Padmini meets Kapila with the transposed head in the forest we find Bhagavata signaling the end of the action by telling the audience,

"There's a break of ten minutes now. Please have some tea ponder over this situation and come back with your solutions. We shall continue with our enquiry." [6]

Hayavadana is therefore a mythological story told in the modern context where the author analyses the situation of the protagonists not leading to catharsis but making the readers ponder about the real reasons of a happiness and contention diverting the tragic end with repose. 


\subsection{Yayati}

The other play under study is Yayati in which the Indian mythological king Yayati is a representative of modern man portrayed in contemporary literature. Karnad has borrowed the myth from great Indian epic Mahabharata and other Puranas. He is an individual tormented and haunted by his own desires. He lives in wretched unhappiness despite of having his son's youth for a long period of time and this seems to be the largest mystery of human existence. He is an embodiment of the modern alienated man. The play opens with the marriage between Yayati and Devayani, the daughter of Shukracharya who is a demons' guru. Karnad is said to have shown the passion of Yayati for enjoying life, which later turns into aloofness and detachment. The nadir of his lust is reached when he asks his sons to exchange their youth with his old age so that he can go back and enjoy bodily pleasures. After years spent in vain effort to quench his desires by indulgence, Karnad takes a deep insight into Yayati's character and shows his passion for the enjoyment of life, which ultimately turns into detachment and aloofness. Yayati is a true ambassador of modern common man, who in spite of having much pleasures of life, still feels impatient and dissatisfied. He takes the youth of Pooru, his youngest son, but soon realizes the impropriety of his shallow action and feels like an alienated common man. Yayati's disillusionment is complete only with saturation. He had his fill but still remains unfulfilled and dissatisfied. He finally came into senses. He returned to Puru and said,

"Dear son, sensual desire is never quenched by indulgence any more than fire is extinguished by pouring oil on it. Take back your youth and rule the kingdom wisely and well."[7]

Yayati then returned to the forest and spent the rest of his days in austerities, meditating upon Brahman, the ultimate reality. In due course, he attained heaven. He also experienced disillusionment and have lost his faith in life in the play. Yayati had everything that one can dream of. He was born as a prince in the mightiest empire of the time and established himself as the greatest warrior of his time. He married the daughter of the most influential sage and had another princess as his wife and also had many sons but despite of all these possessions he could never lead a happy life owing to his unending sensual desires which ultimately made him a pathetic figure in the end. His long span of sensual indulgence is a symbol that indicates the futility of chasing happiness in things that have a definite end. Indulgence only increases thirst, it doesn't quench it. Each climax of happiness ends with sorrow that it is over so soon, followed by a craving to renew, to repeat the pleasure once more. The audience could interpret the cause of his disastrous life and sense his alienation rather than empathesising with him. Consequently Yayati also follows the 'alienation effect' and 'complex seeing' in Brechtian terms "which prevents the audience from losing itself passively and completely in the character created by the actor, and which consequently leads the audience to be a consciously critical observer." [8]

The characters in these plays are incomplete and alienated despite of accomplishing their desires. In both the plays Karnad has attempted to modernize even the myth and in turn alienate the audience from the conventional theatrical norms to stimulate their thinking capacity. Upholding the rich cultural heritage of India by using myths and traditional stories in his plays Karnad has succeeded in providing romantic charm to his plays. Though rooted in ancient Indian legends, myths, folktales, history his dramas are not far from the contemporary issues of identity crisis and alienation of common man. In Aristotelian theatre, the playwright achieves the desired effect by keeping the audience in a "trance like" state and the dramatic emphasis is on what is going to happen. But in Brechtian theatre, the stress is upon why the event has happened, what caused it and how it can be prevented from happening again." [9] He regarded a theatre of illusion and identification as obscene, and identification with the characters on the stage appeared equally low to him. The theater must not attempt at creating an illusion of present reality. The epic theater is strictly historical; it constantly reminds the audience that it is merely getting a report of past events. Brecht discouraged the audience from losing critical detachment by identification with one or more of the characters. Instead they should maintain a separate existence by being keeping their identities apart, alien and strange.

\section{Conclusion}

The influence of western dramatic theatre cannot be ignored as it helps the native dramatists to dwell on novelty and effectiveness. This search for a naturalistic technique made Karnad follow Brechtian impact in his plays.The Brechtian 'Epic Theatre' opposes the theatre of illusion as proposed by Aristotle. Along with the recreation of established norms and traditions, Karnad has emphasized on the emotional relief obtained by the audience in their own individualistic states. Karnad delves deep into the traditional myths to spell modern man's anguish and dilemmas that are created in his mind. He does not take the myths in their entirety rather picks only fragments that are useful to him and the rest he supplements with his imagination to make his plots interesting. Karnad's profound skill is at its fullest play when he fantasies the exchange of ages between father and son in Yayati and mix-up the heads and the bodies of the friends in Hayavadana. But these improbable situations are not accepted as it is rather viewed in terms of modern psychology.In this way Both Brecht and Karnad reveal and establish modern man's relationship with the past and explored the dimensions of contemporary problems by placing continuous parallel between antiquity and contemporaneity. Apart from the purgation of the 
elements of 'pity and fear' the audience is rendered capable of rationalizing the dramatic situations after witnessing the drama. Karnad traversing the path paved by Brecht renounces the classical principle of pity and fear and favours of the process of alienation of modern man.

\section{References}

[1] Girish.Karnad, “Author's Introduction” to Three Plays (Delhi, O.U.P,1994).

[2] David Daiches, Critical Approaches to Literature (London, Orient Longmans, 1967).

[3] Neeru Tandon, Perspectives and Challenges in Indian English Drama( New Delhi, Atlantic Pub., 2006).

[4] Eric Bentley, The Brecht Commentaries (London, Eyre Methuen, 1981)

[5] R.K. Dhawan, 20 Years of Indian Writing (New Delhi, IAES, 1999).

[6] Girish. Karnad, Hayavandana (New Delhi, Oxford UP, 1988).

[7] Girish Karnad, Yayati. (New Delhi ,Oxford UP, 2007).

[8] John Willett, ed. and trans., Brecht on Theater (New York, Hill and Wang, 1964).

[9] T. Marx, Brechtian Impact on Girish Karnad in K.Balachandran, (Ed), Critical Essays On Commonwealth Literature (New Delhi: Sarup and sons. 2006)149-161. 